\title{
IDENTIFICATION AND ETHNOBOTANICAL SURVEY OF MEDICINAL PLANTS IN VATHALMALAI HILLS, EASTERN GHATS, DHARMAPURI DISTRICT, TAMIL NADU, INDIA
}

\author{
LOGANATHAN S, SELVAM K* \\ Department of Botany, School of Life Sciences, Periyar University, Periyar Palkalai Nagar, Salem, Tamil Nadu, India. \\ Email: selsarat@yahoo.com
}

Received: 05 February 2018, Revised and Accepted: 15 March 2018

\section{ABSTRACT}

Objective: Identification and ethnobotanical survey was made on the utilization of medicinal plant the tribal community of Vathalmalai Hills in Dharmapuri, Tamil Nadu, India. The objective of the study was to identify and documented the medicinal plants traditionally used by tribal people.

Methods: The study was conducted from October 2016 to October 2017. The data were collected from local tribal community, they were interviewed using semi-structured questionnaires, and their traditional ethnomedicinal knowledge was recorded. As, we had collecting the information through local tribal peoples, they we are know the plant local names as well as which plants and parts are mostly used in various disease and disorders problems.

Results: A total of 82 plant species and belonging to 40 families were identified. They are most frequently used plant parts leaf and most of the medicine prepared in the form powder and paste. The important disease cure for cold, diarrhea, chicken pox, smallpox, cough, headache, and stomach ache.

Conclusion: The ethnomedicinal survey of medicinal plants recommended by traditional healers for the treatment of various disease and disorders new areas of research on the antihypertensive effect of medicinal plants. In the case of safety and effectiveness, they can be refined and processed to produce natural drugs.

Keywords: Ethnobotanical survey, Tribal people, Vathalmalai, Ethnomedicines.

(C) 2018 The Authors. Published by Innovare Academic Sciences Pvt Ltd. This is an open access article under the CC BY license (http://creativecommons. org/licenses/by/4. 0/) DOI: http://dx.doi.org/10.22159/ajpcr.2018.v11i6.24884

\section{INTRODUCTION}

The Rig-Veda period $4500 \mathrm{BC}-1600 \mathrm{BC}$ is believed to be the oldest repository of human knowledge about medicinal usages of plants in the Indian subcontinent [1]. WHO quoting is very significant as they are focused worldwide. So that, we had mentioned their reports for percentage. Ethnobotany is two words "Ethno and Botany," and the term was coined by John William Harshberger in the 1890s. It is defined as the study of the relationship between people and plants. Ethnobotanical studies reveal us a complete information about plants and their herbal uses of medicinal plants [2].

India has one of the 12 mega biodiversity countries of the world and is recognized as a country that is rich in all types of biodiversity such as ecosystem, species, and genetic diversity mainly due to its tropical location, disparate physical features, and climatic types are present [3]. India has one of the richest traditionally used medicinal plant in the country. Whether it is distributed to be around 25,000 effective plant-based formulations are known to rural communities in India and are used as folk medicine [4]. Tribal community in India 427 tribal had known the traditional medicine. The knowledge base and the practice have been marginalized due to political, social, and economic reasons of late, interest in traditional medicine has continuously been increasing, and thereby various ethnobotanical studies have been initiated to explore the knowledge base from the various tribal groups $[5,6]$.

Vathalmalai (or) Vytla hills are a small village in Dharmapuri district, Tamil Nadu, India. Vytla hills consisting of seven villages such as Kothalangkadu, Chinnagkadu, Ondriyangkadu, Paalsilmbu, Mannaguli, Periyur, Nayakkanur. It has most of the flora have disappeared due to severe habitat fragmentation resultant from the creation of the plantations. However, some species continue to survive and thrive in several protected areas nearby, include Servarayan hills Yercaud. The tribal people are closely related to the forest environment with which they traditionally live in harmony [7]. Ethnobotanical study focused on the hills of Vathalmalai, it has been variety of flora and knowledge of traditional medicine. The main objective of the study to identify medicinal plants species used by the tribal community of Vathalmalai hills and document the traditional medicinal knowledge associated with the use of these plants.

\section{METHODS}

Study area

The present survey was conducted in Vathalmalai or Vytla hills. It is located in Dharmapuri district, Tamil Nadu, India. It is Reserve forest. The area lies between latitude $12^{\circ} 64^{\prime} \mathrm{N}$ and longitude 78 $20^{\prime} \mathrm{E}$ at an altitude ranging from $3600 \mathrm{~m}$. The temperature ranges between 22 and $25^{\circ} \mathrm{C}$. Vathalmalai is green and natural hill range, Soils of the Vathalmalai hills are mainly Red soil, Blackish brown, and Reddish brown.

\section{People}

The presented tribal people in Vathalmalai hills they were called as Vedar. Tribal community of Vathalmalai hills basically farmers. They are hardworking and economically backward. The tribal people professionally work for collection of honey bee, wax, and other minor forest products. The Various cropping and agricultural practices followed by around the study area has mentioned. Although agricultural modern techniques grown, they are followed the traditional methods.

\section{Data collection}

Frequently, the field survey conducted on (October 2016-October 2017). The Ethnobotanical data were collected through discussions among the herbal practitioners in the study area. Most of the 
information was gathered from elderly people of tribal. The collected plants species were identified using the flora of Presidency of Madras (Gamble, 1935) and the Flora of Tamil Nadu Carnatic (Mathew, 1983). The identified plant specimens were than confirmed with the herbaria of Botanical Survey of India (BSI), southern circle, Coimbatore, Tamil Nadu, India.

\section{RESULTS AND DISCUSSION}

The ethnomedicinal system has been used in various part of the countries since ancient times and it is the best treatment at that time from tribal people community. The present study resulted in the collection of 82 plants species and belonging to 40 families of Angiosperms were identified. The medicinal plants are arranged by scientific name, common name, Tamil name, family name, plant parts used and therapeutic uses (Table 1). The most dominant families such as Asteraceae, Acanthaceae, Fabaceae, Euphorbiaceae, Lamiaceae, Malvaceae. The data were collected from local tribal people of Vathalmalai hills. As shown in Fig. 1, the plant representation of plant form used in shrub (30\%), herb (50\%), climber (5\%), and tree (10\%). As shown in Fig. 2, the most frequently utilized plant parts percentage were whole plant $(5 \%)$, buds and pulp (7\%), bark $(10 \%)$, stem and seed (12\%), fruit (15\%), flowers (20\%), root (35\%), and leaves 60\%(). Vathalmalai traditional healers medicine prepare in the form of single or complex other plant parts to cure various disease and disorders problems. Mostly prepare of medicine in the form of powder, decoction, and paste. The majority of disease cures such as with cold, cough, headache, stomach ache, dysentery, skin disease, wounds, diabetes, and sexual disorders.

\section{DISCUSSION}

In India, about 7300 plant species are used in traditional health-care systems such as Ayurveda, Siddha, Unani, and folk healing practices. The blooming of traditional medicine industry results in an increasing demand on medicinal plant products. Medicinal plants $90 \%$ derived from natural habitats.

Rajgond Tribal of Haladkeri Village in Bidar district is far away from modern medicine even in the $21^{\text {st }}$ century and is known for their unique way of life and disease management [8]. Jawadhu hill's in Tiruvannamalai district have a huge relations with their surrounding environment condition. The tribal community has not forgotten their age-old ethnicity and traditions. Medicinal plants Knowledge, which are used in their daily life against different ailments still lies with them. The variety flora of Jawadhu Hill's include, a large number of medicinal plants, are present [9].

Tirunelveli Kani tribals used the fruit of Trichopus zeylanicus for body strength, asthma, and venereal disease. It is claimed that one can live for days together without food and still be able to perform rigorous

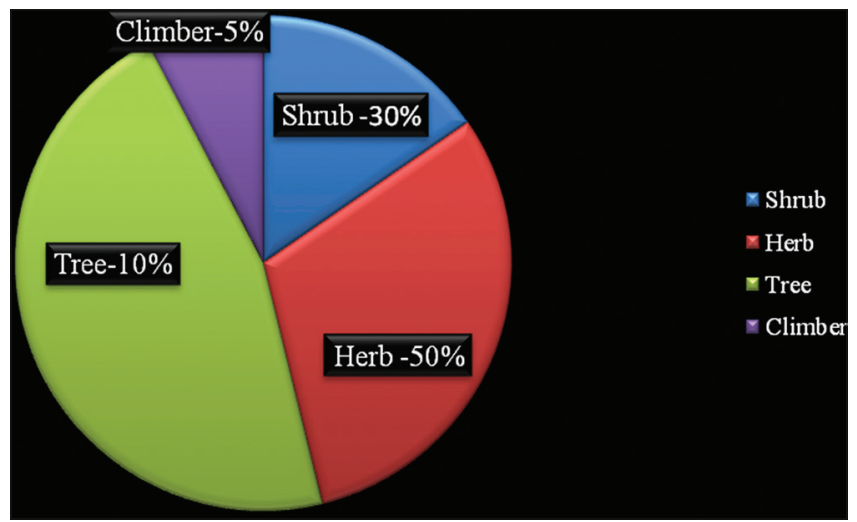

Fig. 1: Habit wise distribution of medicinal plants used by Vathalmalai tribals physical work by eating a few fruits of Arokyapachilai every day and they named the plant as "Arokyapachilai" (greener of health) those are use [10]. Tirunelveli Kani traditional healers used one or more medicinal plant parts than preparation of medicine in the treatment of single or multiple ailments; the similar findings were reported by several researchers [11]. In similar results, Gymnema sylvestre the most generally used medicinal plant, it was attributed to its use in the treatment of various diseases, and it is well recognized by all the informants as an antidiabetic plant. Thanjavur district Irulas tribal people are growing $G$. sylvestre as a climbing vine in their home, and it was a household custom to consume one leaf a day to cure various disease [12]. As Kani traditional healers too frequently use some mixture such as honey, cow goat milk, sugar, ghee, salt, boiled rice, and buttermilk to improve the acceptability and medicinal property of certain remedies [13].

Yercaud hills local tribal people prescribed the medicinally important plants either as single or as in combination with other plants medicine to cure illness problems. An interesting observation was that some of the documented medicinal plants such as Acalypha indica L., G. sylvestre R. Br., Leucas aspera (Willd.) Link, Mimosa pudica L., and Solanum nigrum L. were found to be practiced as important medicinal plants in Yercaud hills for the treatment of such as snake bite, diabetes, headache, dysentery and stomach ulcer [14]. Palamalai traditional healers are used one or more plant parts combination medicine to treating various disease and disorders problems. The local tribal community people are generally dependent on the traditional healthcare system. Traditional knowledge belief in the area also has their own unintentional role in the conservation and sustainable utilization of medicinal plants [15].

In similar results showed Asteraceae family plants have a highly medicinal plant species present compared to Babungo family because of largely available biologically active compound present [16]. Acatochaeta Africana has been found to contain phytochemicals which are capable of arresting wound bleeding, preventing the growth of wound contaminating microbes and accelerating wound healing. Most young people are not interested in traditional medical practice because it is less profitable compared to growing cash crops [17]. Western Ghats is one of the plant biodiversity hotspot of India. Agumbe region of Western Ghats is known for rich plant diversity and traditional medicinal practices. Ten plants were identified to be used to treat fungal infections used exclusively against infectious diseases of both bacteria and fungi in general and skin infections, itching, wound dressing in particular [18].

\section{CONCLUSION}

The study was aimed to indigenous knowledge about medicinal plants used by Vathalmalai terrible people. A total of 82 plant species belonging to 40 plant families were used as medicinal plants for treating of cold, cough, headache, and stomach ache. The knowledge of traditional medicines among the younger population is too poor thus older population can play pivotal role to inherit their knowledge. The medicinal plants of this region require immediate conservation due to urbanization and agriculture practices. Thus, cultivation of these medicinally important plants should to be encouraged.

\section{ACKNOWLEDGMENT}

Authors are thankful to the local people, traditional healers, and forest department officers and my colleagues for providing valuable information and support.

\section{AUTHORS CONTRIBUTIONS}

All the authors have contributed equally.

\section{CONFLICT OF INTERESTS}

Declared none. 


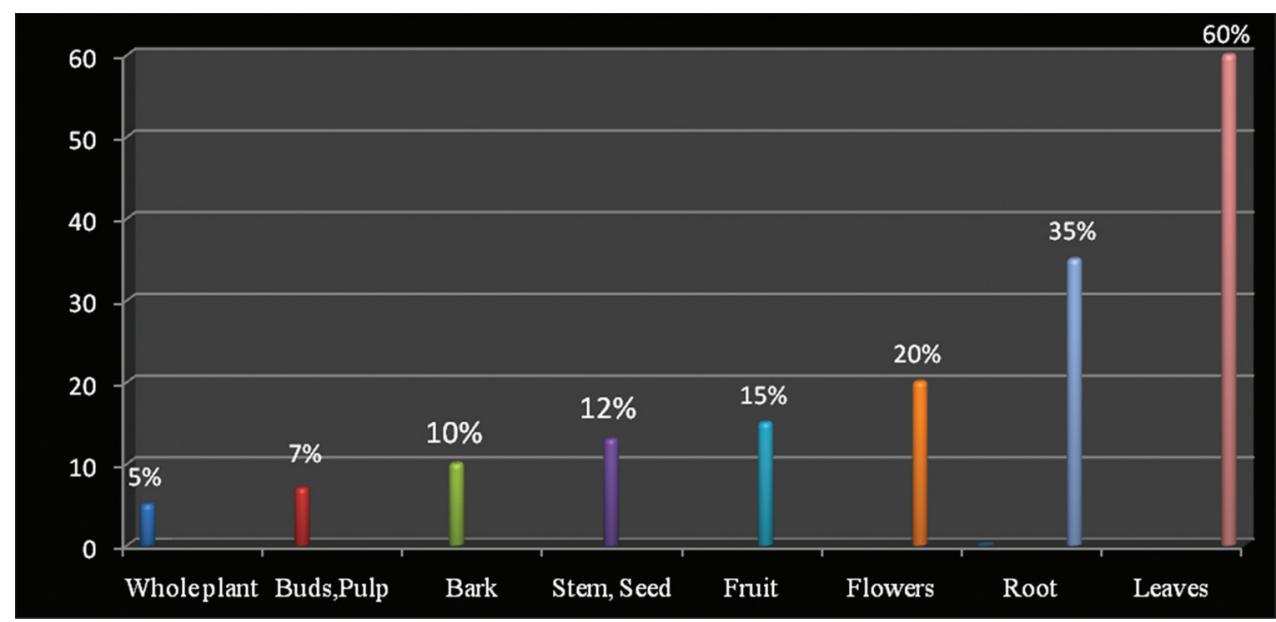

Fig. 2: Medicinal plants parts percentage used in Vathalmalai tribal community

Table 1: Medicinal plants used by local Tribal community from Vathalmalai hills

\begin{tabular}{|c|c|c|c|c|c|}
\hline Scientific name & Common name & Local name & Family & Parts & Therapeutic uses \\
\hline $\begin{array}{l}\text { Ageratina } \\
\text { adenophora }\end{array}$ & Crofton weed & Pachha & Asteraceae & Leaves & $\begin{array}{l}\text { Paste of leaves to treat in wound and skin } \\
\text { disease }\end{array}$ \\
\hline $\begin{array}{l}\text { Ageratum } \\
\text { conyzoides }\end{array}$ & Whiteweed & Pumppillu & Asteraceae & Leaves & $\begin{array}{l}\text { Leaves paste to treat ague, Wounds, } \\
\text { bruises }\end{array}$ \\
\hline Annona squaтosa & Custard apple & Seetha & Annonaceae & Fruits & Fruits to cure Improve digestion \\
\hline Acalypha indica & Indian mercury & Kuppaimeni & Euphorbiaceae & Leaves & $\begin{array}{l}\text { Few leaves soak water then drink the } \\
\text { water to cure Respiratory problems }\end{array}$ \\
\hline Abutilon indicum & Indian Mallow & Thuthi & Malvaceae & Leaves & $\begin{array}{l}\text { Grind leaves with little turmeric apply } \\
\text { wound }\end{array}$ \\
\hline $\begin{array}{l}\text { Achyranthus } \\
\text { aspera }\end{array}$ & $\begin{array}{l}\text { Prickly chaff } \\
\text { flower }\end{array}$ & Naayuruvi & Amaranthaceae & Leaves & $\begin{array}{l}\text { Leaves juice to cure Ear infection and } \\
\text { wounds }\end{array}$ \\
\hline $\begin{array}{l}\text { Amaranthus } \\
\text { spinosus }\end{array}$ & Spiny amaranth & Mullu keerai & Amaranthaceae & Seed, Root & $\begin{array}{l}\text { Seed used for broken bones, Root juice } \\
\text { used for fever, urinary troubles }\end{array}$ \\
\hline Annona reticulata & Bullocks heart & Rama-chitha & Annonaceae & Leaves, Bark & $\begin{array}{l}\text { Fruits and Bark to treat diarrhea and } \\
\text { dysentery }\end{array}$ \\
\hline Acacia nilotica & Babul & Karuvelam & Leguminosae & Bark & Decoction of the bark to treat mouth ulcer \\
\hline Albizia amara & Oil cake tree & Thuringi & Fabaceae & Bark & $\begin{array}{l}\text { Bark used to treat jaundice and mouth } \\
\text { inflammations }\end{array}$ \\
\hline Aloe vera & Katralazhi & Chottu katthallai & Liliaceae & Leaves gel & Leaves gel to treat ulcer, gel apply skin \\
\hline $\begin{array}{l}\text { Artocarpus } \\
\text { integrifolia }\end{array}$ & Jackfruit & Palaa & Moraceae & Fruit & $\begin{array}{l}\text { Eating fruit to cure stomach, indigestion } \\
\text { and increase sperm }\end{array}$ \\
\hline $\begin{array}{l}\text { Alangium } \\
\text { salvifolium }\end{array}$ & Ankol & Alingi & Alangiaceae & Root bark & $\begin{array}{l}\text { The root-bark is also used in traditional } \\
\text { medicine skin problems and snake bite }\end{array}$ \\
\hline Aerva lanata & $\begin{array}{l}\text { Mountain } \\
\text { knotgrass }\end{array}$ & Pulann-chatti & Amaranthaceae & Whole plant & $\begin{array}{l}\text { Decoction of the whole plant to treat } \\
\text { remove the kidney stone and cure urinary } \\
\text { path problems }\end{array}$ \\
\hline Clitoria ternatea & Butterfly pea & Sangu poo & Fabaceae & Leaves & Boiled leaves to treat headache \\
\hline $\begin{array}{l}\text { Crisnum } \\
\text { asiaticum }\end{array}$ & Poison bulb & $\begin{array}{l}\text { Thodavalzhi } \\
\text { kilangu }\end{array}$ & Amaryllidaceae & Leaves & $\begin{array}{l}\text { Leaves juice mixed salt to treat ear- } \\
\text { problems }\end{array}$ \\
\hline $\begin{array}{l}\text { Colocassia } \\
\text { esculenta }\end{array}$ & Green taro & Sempu & Araceae & Leaves & $\begin{array}{l}\text { Decoction of the peel to cure diarrhea, } \\
\text { corm used tribe people to cure ache }\end{array}$ \\
\hline $\begin{array}{l}\text { Cardiospermum } \\
\text { halicacabum }\end{array}$ & Ballon plant & Modikkottan & Sapindaceae & Whole plant & $\begin{array}{l}\text { Leaves juice used for ear problems. } \\
\text { Stomach ache, snakebite. Roots used for } \\
\text { urinary tract problems }\end{array}$ \\
\hline Coccinia indica & Kowai & Cova palam & Cucurbitaceae & Leaves Fruits & Cooking leaves treatment for ulcer \\
\hline $\begin{array}{l}\text { Cissus } \\
\text { quadrangularis }\end{array}$ & Veldt grape & Perandai & Vitaceae & Whole plant & Whole plant to treat stomach and cough \\
\hline $\begin{array}{l}\text { Cipadessa } \\
\text { baccifera }\end{array}$ & Ranabili & Puilipan cheddi & Meliaceae & Root & Root juice used cough and cold \\
\hline Cassia fistula & Indian labburnum & Charak-kondrai & Caesalpiniaceae & Dry, flower & $\begin{array}{l}\text { Decoction of the dry flower to treat } \\
\text { stomach ache and diabetes }\end{array}$ \\
\hline $\begin{array}{l}\text { Capparis } \\
\text { zeylanica }\end{array}$ & Ceylon caper & Suduthoratti & Capparidaceae & Root, Bark & $\begin{array}{l}\text { Decoction of the root bark to treat } \\
\text { vomiting and appetite }\end{array}$ \\
\hline $\begin{array}{l}\text { Citrus } \\
\text { aurantifolia }\end{array}$ & Lime & Elumichai & Rutaceae & Fruits & $\begin{array}{l}\text { Lemon juice, warm water, and sugar to } \\
\text { drink improve liver function }\end{array}$ \\
\hline
\end{tabular}


Table 1: (Continued)

\begin{tabular}{|c|c|c|c|c|c|}
\hline Scientific name & Common name & Local name & Family & Parts & Therapeutic uses \\
\hline Citrus lemon & lemon & Narattai & Rutaceae & Fruits & $\begin{array}{l}\text { Fresh lime juice in warm water to treat } \\
\text { constipation. }\end{array}$ \\
\hline $\begin{array}{l}\text { Diplocyclos } \\
\text { palmatus }\end{array}$ & Lollipop climber & Aiviralk-kovai & Cucurbitaceae & Fruits, Leaves & $\begin{array}{l}\text { Fruits and leaves are used to cure } \\
\text { stomach }\end{array}$ \\
\hline Datura metel & Thornapple & Ummathai & Solanaceae & Seeds, Leaves & Leaves used for Joint pain, headache \\
\hline Euphorbia hirta & Asthma-plant & $\begin{array}{l}\text { Ammam } \\
\text { Paccharisi }\end{array}$ & Euphorbiaceae & Whole plant & Whole plant powder to treat Stomach \\
\hline Emila sonchifolia & Lilac tassel flower & Myalccevi & Asteraceae & Whole plant & $\begin{array}{l}\text { Decoction of the Whole plant to treat } \\
\text { fever }\end{array}$ \\
\hline $\begin{array}{l}\text { Euphorbia } \\
\text { cyathophora }\end{array}$ & Wild Poinsettia & Thithli poo & Euphorbiaceae & Leaves & $\begin{array}{l}\text { Leaves juice to treat stomach-ache and } \\
\text { constipation }\end{array}$ \\
\hline Eclipta prostrate & False Daisy & Karisilanganni & Asteraceae & Fresh Leaves & Eating five fresh leaves cure constipation \\
\hline $\begin{array}{l}\text { Euphorbia } \\
\text { tirucali }\end{array}$ & Pencil tree & Nirgudi & Euphorbiaceae & Root and Bud & $\begin{array}{l}\text { Decoction of the Root and Bud to treat } \\
\text { coughs and pectoral pain }\end{array}$ \\
\hline $\begin{array}{l}\text { Hemidesmus } \\
\text { indicus }\end{array}$ & $\begin{array}{l}\text { Indian } \\
\text { sarsaparilla }\end{array}$ & Nannari & Periplocaceae & Tuber & $\begin{array}{l}\text { Tuber used for tea for stimulate and cure } \\
\text { stomach-pain }\end{array}$ \\
\hline $\begin{array}{l}\text { Hygrophila } \\
\text { auriculata }\end{array}$ & Temple plant & Neer-mulli & Acanthaceae & Whole plant & $\begin{array}{l}\text { Decoction of the whole plant to treat } \\
\text { jaundice, enlarge liver }\end{array}$ \\
\hline $\begin{array}{l}\text { Heliotropium } \\
\text { indicum }\end{array}$ & Indian heliotrope & Tetkkida & Boraginaceae & Leaves & $\begin{array}{l}\text { Leaves with garlic and ginger oral } \\
\text { consumption act as cancer agent }\end{array}$ \\
\hline Ipomoea obscura & Morning Glory & Sirudali & Convolvulaceae & Dry Leaves & Dry powder leaves to treat aphthae \\
\hline $\begin{array}{l}\text { Jasminum } \\
\text { ariculatum }\end{array}$ & Jasmine & Malligai & Oliaceae & Leaves & $\begin{array}{l}\text { The leaves are used in the treatment of } \\
\text { mouth ulcers }\end{array}$ \\
\hline $\begin{array}{l}\text { Jatropha } \\
\text { gossypiltolia }\end{array}$ & Cotton leaf & Kattamanakku & Euphorbiaceae & Bark & $\begin{array}{l}\text { Decoction of the Bark used for stimulate } \\
\text { menstruation }\end{array}$ \\
\hline $\begin{array}{l}\text { Lepidagathis } \\
\text { cristata }\end{array}$ & Mullabanthi & $\begin{array}{l}\text { Karappan } \\
\text { poondu }\end{array}$ & Acanthaceae & Leaves & Leaves extract for treating malaria \\
\hline Lantana camara & Lantana weed & Unnichedi & Verbenaceae & Roots & Fresh root used for dysentery \\
\hline Leucas aspera & Thumbai & Thumma chettu & Lamiaceae & Leaf, Flower & $\begin{array}{l}\text { Decoction of the whole plant cure } \\
\text { malarial fever, leaves juice apply skin } \\
\text { disease, swelling }\end{array}$ \\
\hline Mucuna prurita & $\begin{array}{l}\text { Bengal velvet } \\
\text { bean }\end{array}$ & Poonaikali & Fabaceae & Seeds & Seeds used for male infertility, snake-bites \\
\hline $\begin{array}{l}\text { Madhuca } \\
\text { longifolia }\end{array}$ & lluppai & Illupi & Sapotaceae & Flowers & $\begin{array}{l}\text { Flowers juice to treat headache and eyes } \\
\text { problem. }\end{array}$ \\
\hline Martynia anua & Devil's Claw & Kakatundi & Malvaceae & Leaves & Leaves to treat cure stomach \\
\hline $\begin{array}{l}\text { Melia } \\
\text { azedarachta }\end{array}$ & Bakayan tree & Malai vembu & Meliaceae & Leaves, Bark & $\begin{array}{l}\text { Decoction of the leaves to relief hernia, } \\
\text { Bark decoction to cure kidney problems }\end{array}$ \\
\hline $\begin{array}{l}\text { Momordica } \\
\text { charantia }\end{array}$ & Bitter gourd & Pavai kai & Cucurbitaceae & Fruits, Seeds & $\begin{array}{l}\text { Fruits used for stimulate digestion, Seeds } \\
\text { dry powder decoction used for diabetes }\end{array}$ \\
\hline Mimusops elengi & Bullet wood & Magizhamboo & Sapotaceae & Fruits & Fruits to treat constipation \\
\hline Morinda coreia & Noni & Manchanari & Rubiaceae & Trunk & $\begin{array}{l}\text { The trunk to treat mensturtional } \\
\text { disorders }\end{array}$ \\
\hline Mymosa pudica & Thotta-sinigi & Sensitive plant & Leguminosae & Leaves & Leaves paste used for wounds \\
\hline $\begin{array}{l}\text { Ocimum } \\
\text { tenuifloram }\end{array}$ & Thulsi & Thulasi & Lamiaceae & Leaves & Fresh leaves to treat cough and cold \\
\hline $\begin{array}{l}\text { Ocimum } \\
\text { americanum }\end{array}$ & Hairy Basil & Nai-thulasi & Lamiaceae & Leaves & $\begin{array}{l}\text { Leaves paste to cure skin disease and } \\
\text { apply wounds }\end{array}$ \\
\hline Pavonia odorata & $\begin{array}{l}\text { Fragrant sticky } \\
\text { mallow }\end{array}$ & Anantai & Malvaceae & Whole plant & Leaf juice to cure gonorrhea \\
\hline Passiflora foetida & $\begin{array}{l}\text { Stinking } \\
\text { passionflower }\end{array}$ & Mupparisavalli & Passifloraceae & Whole plant & Whole plant used for liver disorders, fever \\
\hline Psidium guajava & Guava & Коууа & Myrtaceae & Root, Leaves, & Leaf used for malarial fever \\
\hline $\begin{array}{l}\text { Phyllanthus } \\
\text { amarus }\end{array}$ & Stonebreaker & Kila-nelli & Phyllanthaceae & Whole plant & $\begin{array}{l}\text { Root juice and milk to cure jaundice, } \\
\text { decoction of whole plant cure malarial } \\
\text { fever }\end{array}$ \\
\hline $\begin{array}{l}\text { Pergularia } \\
\text { daemia }\end{array}$ & Pergularia & Uttamani & Asclepiadaceae & Leaf, Root & $\begin{array}{l}\text { Root decoction to treat venereal disease, } \\
\text { leaf used for fever }\end{array}$ \\
\hline $\begin{array}{l}\text { Phyllanthus } \\
\text { maderaspatensis }\end{array}$ & Bhumyaamalaki & Arecipudu & Euphorbiaceae & Leaves & Leaves to treat urinary problems \\
\hline $\begin{array}{l}\text { Plectranthus } \\
\text { amboinicus }\end{array}$ & Indian borage & Karpuravalli & Lamiaceae & Leaves & $\begin{array}{l}\text { Leaves are taken internally in the } \\
\text { treatment of coughs and cold }\end{array}$ \\
\hline
\end{tabular}


Table 1: (Continued)

\begin{tabular}{|c|c|c|c|c|c|}
\hline Scientific name & Common name & Local name & Family & Parts & Therapeutic uses \\
\hline Pueraria tuberose & Indian kudzu & $\begin{array}{l}\text { Nilpushni } \\
\text { Kezhugu }\end{array}$ & Fabaceae & Tuber & Tuber used for gastric troubles \\
\hline Rungia repens & Creeping rungia & Pottkanchi & Acanthaceae & Whole plant & Whole plant juice to treat snake-bites \\
\hline Rungia pectinata & Comb rungia & Tavashu & Acanthaceae & Root & Root to treat fever \\
\hline Rivina humilis & Rouge plant & Raatha nalli & phytolaccaceae & Leaves & leaves paste to treating wounds \\
\hline $\begin{array}{l}\text { Randia } \\
\text { dumetorum }\end{array}$ & Madanaphala & Marakkaarai & Rubiaceae & Fruit, Pulp & $\begin{array}{l}\text { Fruit, pulp grinding to cure skin pimples } \\
\text { problems }\end{array}$ \\
\hline $\begin{array}{l}\text { Rhinacanthus } \\
\text { nasutus }\end{array}$ & Snake jasmine & Anichchi & Acanthaceae & Root bark & $\begin{array}{l}\text { Root-bark is a remedy for itching } \\
\text { problems. }\end{array}$ \\
\hline Sida acuta & Broomweed & $\begin{array}{l}\text { Kattu } \\
\text { Karunthaikai }\end{array}$ & Malvaceae & Whole plant & Decoction of the whole plant cure fever \\
\hline Solanum indicum & Indian nightshade & Anachundai & Solanaceae & $\begin{array}{l}\text { Roots, } \\
\text { Berries }\end{array}$ & $\begin{array}{l}\text { Prevent asthma attacks, cardiac disorders, } \\
\text { improve digestion strength, cure skin } \\
\text { disease }\end{array}$ \\
\hline $\begin{array}{l}\text { Sphaeranthus } \\
\text { indicus }\end{array}$ & $\begin{array}{l}\text { Indian } \\
\text { sphaeranthus }\end{array}$ & Visnukkarantai & Asteraceae & Bark & Bark soaked water to treat diarrhea \\
\hline $\begin{array}{l}\text { Solanum } \\
\text { trilobatum }\end{array}$ & Purple pea & Thoothuvalai & Solanaceae & Leaves & $\begin{array}{l}\text { Boiled leaf then filter the water and some } \\
\text { amount of milk add to treat for cold }\end{array}$ \\
\hline $\begin{array}{l}\text { Synedrella } \\
\text { nodiflora }\end{array}$ & Node weed & $\begin{array}{l}\text { Mudiyan } \\
\text { pachchai }\end{array}$ & Asteraceae & Leaves & Leaf used for ear and stomach-ache. \\
\hline Sida cordata & Long-stalk Sida, & Palampasi & Malvaceae & Whole plant & $\begin{array}{l}\text { Whole plant juice to apply boils and } \\
\text { pimples }\end{array}$ \\
\hline $\begin{array}{l}\text { Semecarpus } \\
\text { anacardium }\end{array}$ & Geeru beeja & Cen-kottai & Anacardiaceae & Seeds & Seed oil to treat Wound. \\
\hline $\begin{array}{l}\text { Strychnos } \\
\text { potatorum }\end{array}$ & Clearing-nut tree & Thethankottai & Loganiaceae & Bark & In-site bark to treat skin pimples \\
\hline Tecoma stants & Trumpet flower & Sonnapatti & Bignoniaceae & Root, Leaves & $\begin{array}{l}\text { Leaves to cure diabetes and stomach } \\
\text { problems }\end{array}$ \\
\hline $\begin{array}{l}\text { Tephrosia } \\
\text { purpurea }\end{array}$ & Wild indigo & Kollukkai Velai & Fabaceae & Whole plant & $\begin{array}{l}\text { Whole plant to cure liver, kidney } \\
\text { problems, skin disease, Relief body pain }\end{array}$ \\
\hline $\begin{array}{l}\text { Tinospora } \\
\text { cortifolia }\end{array}$ & Guduchi & Shindilakodi & Menispermaceae & Stem & $\begin{array}{l}\text { Stem juice to cure many types of cancers, } \\
\text { gout, liver disease }\end{array}$ \\
\hline $\begin{array}{l}\text { Tridax } \\
\text { procumbens }\end{array}$ & Coat buttons & $\begin{array}{l}\text { Vettukkaaya- } \\
\text { thalai }\end{array}$ & Asteraceae & Leaves & $\begin{array}{l}\text { Leaves Decoction and paste is bound on } \\
\text { wound caused by cut. }\end{array}$ \\
\hline Veronica agrestis & Field speedwell & Ottu chetti & Plantaginaceae & Whole plant & $\begin{array}{l}\text { Decoction of the whole to treat relief pain } \\
\text { in menstruation }\end{array}$ \\
\hline $\begin{array}{l}\text { Ziziphus } \\
\text { xylopyrus }\end{array}$ & Woody fruited & Suraipalam & Rhamnaceae & Root-Bark & Root bark to treat asthma, diarrhea \\
\hline
\end{tabular}

\section{REFERENCE}

1. Puspangadan PS. Ethno-Botany in India: A Study Report. New Delhi: Government of India; 1995.

2. Rahul J. An Ethno-botanical study of medicinal plants in Taindol Village, District Jhansi, Region of Bundelkhand, Uttar Pradesh. J Med Plants Res 2013;1:59-71.

3. Jain SK. Ethno-botany. Its scope and study. Indian Museum Bull 1967;2:39-43

4. Shukla AN, Srivastava S, Rawat AK. An Ethno-botanical study of Rewa district, Madhya Pradesh. Indian J Tradit Knowl 2010;9:191-202.

5. Jain AK, Patole SN. Less-known medicinal uses of plants among some tribal and rural communities of pachmarchi forest (MP). Ethnobotany 2001;13:96-100.

6. Ignaciuthu S, Ayyanar M, Sivaraman KS. Ethnobotanical investigations among tribes in Madurai district of Tamil Nadu (India). Ethnobiol Ethnomed 2006;2:25-30.

7. Kadavul K, Dixit AK. Ethno-medicinal studies of the woody species of Kalrayan and Shervarayan Hills, Eastern Ghats, Tamil Nadu. India J Tradit Knowl 2009;8:592-7.

8. Pooja GS, Vidyasagar M. Ethnomedicinal plants used by Rajgond Tribes of Haladkeri village in bidar district, Karnataka, India. Asian J Pharm Clin Res 2015;7:216-20.

9. Ranganathan R, Vijayalakshmi R, Parmeswari P. Ethnomedicinal survey of Jawadhu hills in Tamil Nadu, Asian J Pharm Clin Res 2012;5:45-9.

10. Pushpangadan P. 'Arogyappacha' (Trichopus zeylanicus): The
'Ginseng' of Kani tribes of Agasthiyar hills (Kerala) for evergreen health and vitality. Anc Sci Life 1988;8:13-6.

11. Ignacimuthu S, Ayyanar M, Sankarasivaraman K. Ethno-botanical study of medicinal plants used by Paliyar tribals in Theni district of Tamil Nadu, India. Fitoterapia 2008;79:562-8.

12. Ragupathy S, Newmaster SG. Valorizing the 'Irulas' traditional knowledge of medicinal plants in the Kodiakkarai Reserve Forest, India. J Ethnobiol Ethnomed 2009;5:10.

13. Poonam K, Sing GS. Ethnobotanical study of medicinal plants used by the Taungya community in Terai Arc Landscape, India. J Ethnopharmacol 2009;123:167-76.

14. Udayan PS, Satheesh George Tushar KV, Balachandran I. Medicinal plants used the Malayali tribe of Servarayan Hills, Yercaud, Salem district, Tamil Nadu, India. Zoo's Print J 2006;21:2223-4.

15. Kumudha P, Yogeshwari C. Ethnobotanical survey of medicinal plants in Palamalai hills area, Salem district, Tamil Nadu. Int J Plant Anim Environ Sci 2016;6:139-51.

16. Heinrich M, Robles M, West JE, Ortiz de Montellano BR, Rodriguez E. Ethno-pharmacology of Mexican Asteraceae (Compositae). Ann Rev Pharmacol Toxicol 1999;38:539-65.

17. Okoli CO, Akah PA, Okoli AS. Potentials of leaves of Aspilia Africana (Compositae) in wound care: An experimental evaluation. BMC Complement Altern Med 2007;7:24.

18. Nagabhushan K, Raveesha A. Ethno-botanical survey and scientific validation of medicinal plants used in the treatment of fungal infections in agumbe region of western ghats, India. Int J Pharm Pharm Sci $2015 ; 7: 273-7$ 